\title{
Soil Erosion Modeling Using GIS Based RUSEL Model in Gilgel Gibe-1 Catchment, South West Ethiopia
}

\author{
Gizaw Tesfaye* and Degifie Tibebe \\ Ethiopian Institute of Agricultural Research, Ethiopia \\ Submission: November 21, 2018; Published: December 13, 2018 \\ *Corresponding author: Gizaw Tesfaye, Ethiopian Institute of Agricultural Research, Ethiopia
}

\begin{abstract}
This study was aimed to estimate soil loss in Gilgel Gibe- 1 catchment by GIS-based RUSLE model and prioritize sub-watersheds for soil conservation planning. Both primary and secondary data from different sources were used in this study. The amount of soil loss from the catchment is estimated with GIS-based RUSLE model which uses the rainfall-runoff erosivity, soil erodibility, topographic effect, soil/surface coverage and land management practice of the catchment as an input. The result of the study shows the mean annual soil loss of the catchment is $62.98 \mathrm{t}$ ha-1year-1 which is about $26.56 \times 106$ ton year-1. Erosion 'hotspot' areas are identified and prioritized on the bases of soil loss. Accordingly, SW4, SW3, SW5, SW6, SW9, SW8, SW7, SW2, and SW1 got 1 to 9 priority level respectively. $35.2 \%$ of the catchment area is covered by soil loss class ranging $0-5$ t ha-1year- 1 and about $56 \%$ of the catchment have soil loss greater than a tolerable level which is $11 \mathrm{t}$ ha- 1 year- 1 . The result of this study indicates the catchment and reservoir were under a problem of soil loss and siltation. Therefore, this study recommends immediate action, soil and water conservation measures, should be taken in the catchment according to the priority of sub-watershed and, also a detailed study is appreciated, especially on experimental test plots.
\end{abstract}

Keywords: GIS; Prioritization; Rusle; Sub-Watershed; Soil Loss

\section{Introduction}

Soil erosion is a serious problem in the Ethiopian highland areas that increased sedimentation of reservoirs and lakes [1]. Rapid population growth, cultivation on steep slopes, clearing of vegetation and overgrazing are the main factors that accelerate soil erosion in Ethiopia. In Ethiopia, soil erosion and nutrient depletion have been one of the most important environmental problems [2]. Rapid land use changes due to intensive agricultural practices in the Ethiopian highlands results in increasing rate of soil erosion [3]. The trans-boundary rivers that originate from the Ethiopian highlands carry about 1.3 billion tons/year of sediment to neighboring countries whereas the Blue Nile alone carries 131 million tons/year [4]. In terms of soil loss due to erosion, estimates vary by locations, which reflects the varying Ethiopian landscape, management practices and soil characteristics within and between sub-basins [5]. measured soil erosion rates on test plots and estimated a loss of 130 to 170 ton ha- $1 \mathrm{yr}^{-1}$ on cultivated land. Furthermore, the average annual soil loss in Medego watershed in the north of Ethiopia was estimated at $9.6 \mathrm{t} \mathrm{ha}^{-1} \mathrm{yr}^{-1}$ [6].

Previous studies reported Gilgel Gibe- 1 catchment is under a serious problem of soil erosion and a rapid loss of storage volume due to excessive soil erosion and subsequent sedimentation in Gilgel Gibe-1 dam reservoir. Deforestation, land degradation due to poor land management practices associated with the rugged topography and the erosive rainfall, landslides, river bank erosion and gullies are reported as the main cause of the problem the catchment [7-11]. However, these studies didn't identify hotspot areas in the catchment which is very important to take immediate action against the problem in terms of time and budget. In addition to this, varying results were reported on the amount of soil erosion rate in the catchment. Because of this, the study was aimed to estimate soil erosion rate with GISbased RUSLE model and prioritize sub-watersheds for soil and water conservation planning in Gilgel Gibe- 1 catchment. The most widely-used model for erosion assessment and conservation planning is the empirically-based Universal Soil Loss Equation (USLE) and its direct offshoots, the Revised USLE (RUSLE) and Modified USLE (MUSLE). RUSLE is the model one of the most technically advanced and showing potential for use in other parts of the world, including developing countries [12]. The combined use of Geographical Information Systems (GIS) and RUSLE was selected because of their consideration of spatial distribution and applicability to watersheds and the inputs needed for the model is not complex and flexible [13].

\section{Materials and Methods}

\section{Description of the study area}

Gilgel Gibe-1 catchment is located in South West part of Ethiopia in Jimma zone of Oromia Regional State in Omo-Ghibe basin with a total area of $4218 \mathrm{~km}^{2}$ at the dam site(outlet) and it is 
located in between 7o19'07.15" and 8012'09.49"N latitudes and $36031^{\prime} 42.60^{\prime \prime} \mathrm{t} \quad$ o 37o25`16.05”E longitudes. The catchment was generally characterized by rouged topography and was heterogeneous, with upper plateaus that are cut by deep V-shaped valleys in the flanks and flat river terraces around the Gilgel Ghibe River in the center of the catchment with an average elevation of about 1700m above mean sea level Demissie et al. [14] (Figure 1). The seasonal rainfall distribution takes a uni-modal pattern and it is maximum during the summer and minimum during the winter season, influenced by the intertropical convergence zone (ITCZ) Demissie et al. [14]. The Gilgel Gibe catchment was characterized by a wet climate with an average annual rainfall of about $1347 \mathrm{~mm}$ and an average temperature of $19{ }^{\circ} \mathrm{C}$ with $24.78{ }^{\circ} \mathrm{C}$ maximum temperature and $11.58{ }^{\circ} \mathrm{C}$ minimum temperature. The geology of the catchment is related to the uplifting of the East African rift valley in the Upper Eocene [15]. The major soil types in the study area were Nitisols, Fluvisols, Acrisols, and Vertisols, with the Nitisol domination [16]. The catchment is largely comprised of cultivated land and grazing land. In the upper part of the catchment coffee based forest was common. Generally, a mixed farming system is common in the study area Broothaerts et al. [17].

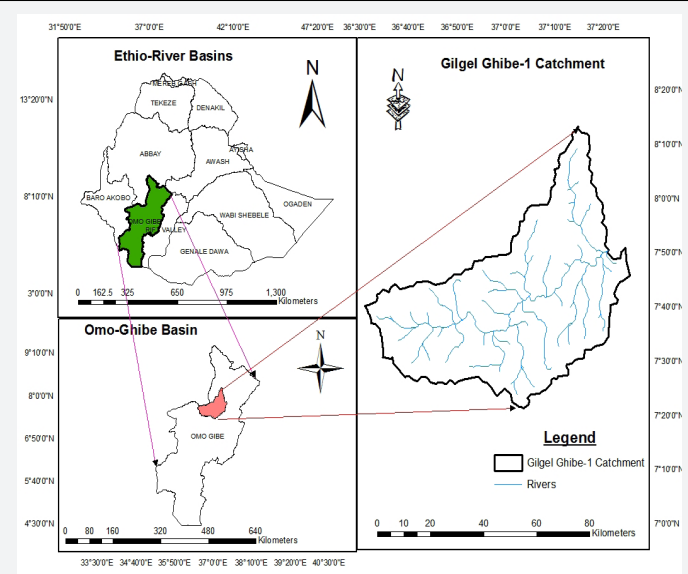

Figure 1: Location map of the study area.

\section{Application of RUSLE Models for soil erosion}

GIS techniques were integrated with Revised Universal Soil Loss Equation (RUSLE) empirical soil loss model to estimate mean annual soil loss (A) of the catchment. In the application of RUSLE on GIS environment, soil loss was estimated at a grid or cell level with a size of $30 \times 30 \mathrm{~m}$. Raster models are cell-based representations of map features, which allow fast processing of map layer overlay operations [18]. Five major factors (rainfall pattern, soil type, topography, crop system, and management practices) were used in RUSLE for computing the average annual soil erosion expected on the field slopes and are represented in the equation Renard et al. [19]:

$$
A=R^{*} K^{*} L S^{*} C^{*} P
$$

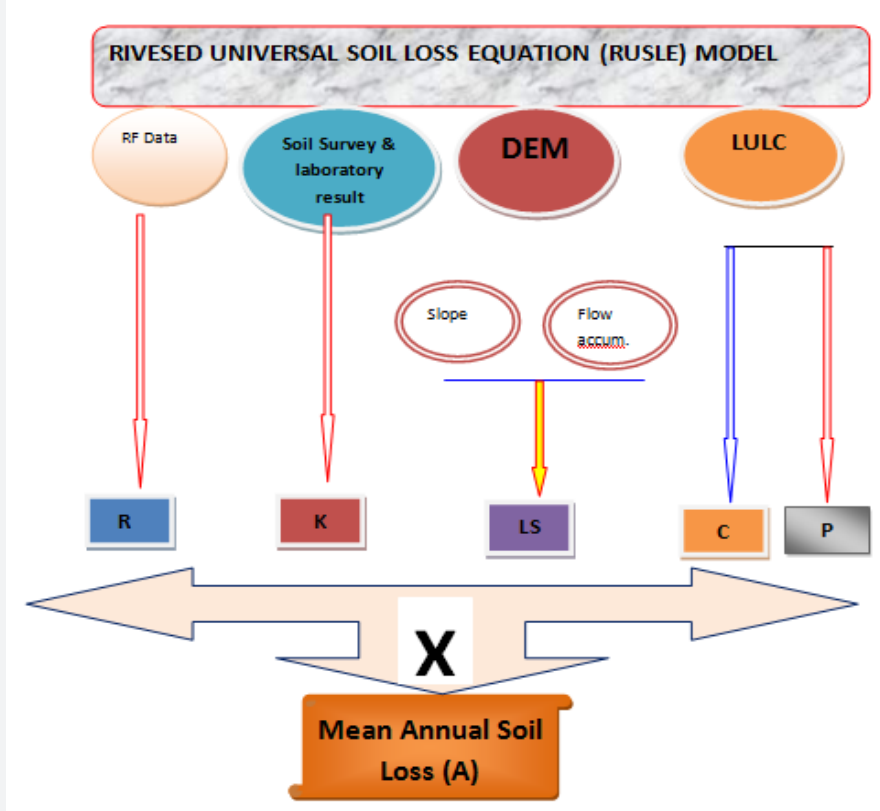

Figure 2: Set up of RUSLE models for soil loss estimation. 
Where: $A=$ is the computed spatial average soil loss and temporal average soil loss per unit area ( $\mathrm{t} / \mathrm{ha} / \mathrm{year}), \mathrm{R}=$ the rainfall-runoff erosivity factor (MJ $\mathrm{mm} /($ ha $h \mathrm{yr}$ )), $\mathrm{K}=$ the soil erodibility factor ( $\mathrm{t}$ ha $\mathrm{h} /($ ha $\mathrm{MJ} \mathrm{mm})$ ), $\mathrm{L}=$ the slope-length factor, $\mathrm{S}=$ the slope steepness factor, $\mathrm{C}=$ the cover management factor and $\mathrm{P}=$ the conservation support practice factor. Maps of RUSLE parameters viz. R, K, LS, C, and P, were overlaid to form a combined map of the composite term R.K.LS.C.P which gives the spatial average soil loss and temporal average soil loss per unit area (tons ha $^{-1} \mathrm{yr}^{-1}$ ). Mean annual soil loss of the catchment was calculated as a summation of the product of each pixel value with pixel area and divided with the total catchment area (Figure 2).

\section{Determination of RUSEL Model parameters}

Rainfall-Runoff Erosivity (R) Factor: The erosivity factor of rainfall $(R)$ is the product of kinetic energy of the raindrop and the 30-minute maximum rainfall intensity. In areas where rainfall intensity data are not available attempts have been made Jain et al. [20] to determine erosivity from daily rainfall data. In Gilgel Gibe-1 catchment, 30-minute rainfall intensity data was not available, and the R-factor value was estimated from mean annual rainfall data by the regression equation developed by Zelalem [21] for Oromia Regional State. The regression equation for around the study area was: $\mathrm{R}=0.002 \mathrm{P} 2-4.89 \mathrm{P}+5996.11$. Where $\mathrm{R}$ is the rainfall-runoff erosivity factor (MJ-mm/ha.year) and $P$ is the mean annual rainfall $(\mathrm{mm})$. daily precipitation data for four stations (Dedo, Jimma, Asendabo, and Gibe) in the catchment and four neighboring stations (Shebe, Agaro, Sekoru and Limmu) were taken from National Meteorological Agency for 30 years (1985-2015) and checked for missing data, homogeneity and consistency before using it for further analysis. Using mean annual precipitation of each stations R-factor value was calculated and mapped with raster calculator tool in GIS, and R-factor map was generated as a raster through interpolation using 'Kriging' method in spatial analysis tool in Arc GIS environment.

Soil Erodibility (K) Factor: The soil erodibility factor is based on the soil texture, structure, organic matter, and permeability. The soil survey was conducted throughout the catchment and a total of 283 soil samples were collected and composited into 119 composite soil samples for soil textural class analysis (hydrometer method) and analysis of organic matter (Walkley black method) in Jimma Agricultural Research Center, Soil and plant tissue analysis laboratory. Soil structure was identified on the field during soil survey for each soil samples. Soil permeability was obtained from the relation between soil textural classes and permeability rate developed by Wischmeir et al. [22]. Using the equation developed by [19] soil erodibility factor (K-value) for each soil sample was calculated and soil erodibility map was generated as a raster data through interpolation by 'Kriging' method.

$$
K=\frac{[2.1 M 1.14 \times 10-4(12-a)+3.25(b-2)+2.5(c-3)]}{100}
$$

Where, $M$ = particle size parameter; (percent silt + percent very fine sand) (100-percent clay), $a=$ percent organic matter, $b=$ soil structure code used in soil classification; (very fine granular= 1 , fine granular $=2$, medium or coarse granular $=3$, blocky, platy or massive $=4$ ) and $c=$ soil permeability class; (rapid $=1$, moderate to rapid $=2$, moderate $=3$, slow to moderate $=4$, slow $=5$, very slow =6). Slope Length and Steepness (LS) Factor: The $L$ and $S$ factors represent the effects of slope length $(L)$ and slope steepness $(S)$ on soil erosion. LS-factor was calculated by Unit Stream Power Erosion and Deposition (USPED) method, which uses the raster calculation between flow accumulation and slope of watershed, because it is obvious that it can be done with the tools included in a normal ArcGIS [23]. The formula below was used into raster calculator to generate LS-factor map.

$L S=$ Power $($ “flow accumulation"* [cell resolution] $/ 22.1,0.4) * \operatorname{Power}(\operatorname{Sin}($ "slope in degree"* 0.01745$)) / 0.09,1.4) * 1.4$.

Cover (C) Factor: Landsat image taken in 2016 was preprocessed and classified for land use land cover with the help of both GIS 10.1 and ERDAS IMAGINE 2013 through supervised classification system. Image preprocessing involves the correction of distortion of images, degradation of images, and removal of the cloud if there. The catchment land use type was classified into six major land use classes namely, cultivation land, grazing land, dense forest land, open forest land and water body and settlement area or build up lands. C-values given by different scholars for different land use classes were used to map cover factor by reclassifying land use land cover map.

Management (P) Factor: The support practice affects erosion primarily by modifying the flow pattern, grade, and direction of surface runoff and by reducing runoff amount and rate. The conservation practice factor is related to certain soil conservation measures, which reduce the effects of slopes on soil erosion Mati and Veihe [24]. The P factor relates to supporting practices and indicates reduced soil erosion potential due to farming practices and conservation measures. Nyssen et al. [25] adapted the P-factor values for Ethiopian condition by dividing P-factor into sub-factors $(\mathrm{Pc}=$ plowing and cropping practices sub-factors, $\mathrm{PN}=$ conservation structures sub-factor and $\mathrm{PM}=$ in situ conservation practices sub-factors). For cultivation of land, the P-factor value was the product of Pc, PN, and PM; while for other land use types, the P-value is only equal to the value of PN. Based on the assigned P-values for different land uses, support practice factor map was generated by reclassifying land use type map with the help of spatial analysis tools in ArcGIS.

Prioritization of Watersheds: The catchment soil loss map was classified into different severity classes $0-5$ ton ha-1 year-1 as slight, 5-10 ton ha ${ }^{-1}$ year $^{-1}$ as moderate, 10-20 ton ha ${ }^{-1}$ year $^{-1}$ as high, 20-40 ton ha ${ }^{-1}$ year $^{-1}$ as very high, 40-80 ton ha $^{-1}$ year $^{-1}$ as severe and greater than 80 ton ha- ${ }^{-1}$ year ${ }^{-1}$ as very severe on the bases of soil loss Morgan [26] and Pandey et al. [27]. Sub-watershed with high soil loss are given first priority and with the least value of soil loss are given last priority. Sub-watersheds of the catchment were categorized into 5 classes, 40-50-ton ha ${ }^{-1}$ year ${ }^{-1}$ slight, 50-60 ton ha ${ }^{-1}$ year-1 moderate, 60-70 ton ha $^{-1}$ year $^{-1}$ high, and $70-80$ ton ha $^{-1}$ year ${ }^{-1}$ very high, and $>80$ ton ha $^{-1}$ year $^{-1}$ severe and prioritized from 1 to 9 by descending order. 


\section{Results and Discussion}

\section{Estimated RUSLE Model Parameters}

The rainfall stations affecting the rainfall erosivity of Gilgel Ghibe-1 catchment were identified with the help of Thiessen polygon and shown in Figure 3 below. Accordingly, four stations (Dedo, Jimma, Ghibe and Asendabo) were found within the catchment while the other four stations (Shebe, Agaro, Limmu Genet and Sekoru) were around the catchment and influences the mean rainfall of the catchment (Figure 3). It was observed that the highest rainfall and R-value was occurred in the upper part of the catchment and lowest at the middle and near the outlet (Figure 4). The rainfall runoff erosivity of the catchment was resulted ranging from 3618.3 to 3010.59 with a mean value of $3198.97 \mathrm{MJ} \mathrm{mm} \mathrm{ha}^{-1}$ year $^{-1}$ and standard deviation of 75.00. Rainfall stations having high rainfall had resulted high rainfall runoff erosivity value which may cause high soil erosion (Figure 4). Soil Erodibility factor (K) represents the susceptibility of soil or surface material to erosion, transportability of the sediment, and $\mathrm{K}$ - factor value of the catchment was found on the bases of texture; \% silt, \%very fine sand, \% sand, \% organic matter, soil structure, and permeability rate of the soil in the catchment using. Soil textural classes of the catchment ranges from clay to sandy clay with sandy clay loam domination. Clay and sandy soils have low $\mathrm{K}$ value because of resistant to detachment and high infiltration rates respectively. Silt loam soils have moderate to high $\mathrm{K}$ values, as the soil particles are moderately to easily detachable, infiltration is moderate to low. According to the result of soil physico-chemical properties in the catchment obtained from laboratory, the soil erodibility map of the catchment was resulted ranging from 0.28 to 0.417 with a mean value of 0.358 ha h ha- $1 \mathrm{MJ}-1 \mathrm{~mm}-1$ and 0.36 standard deviation.

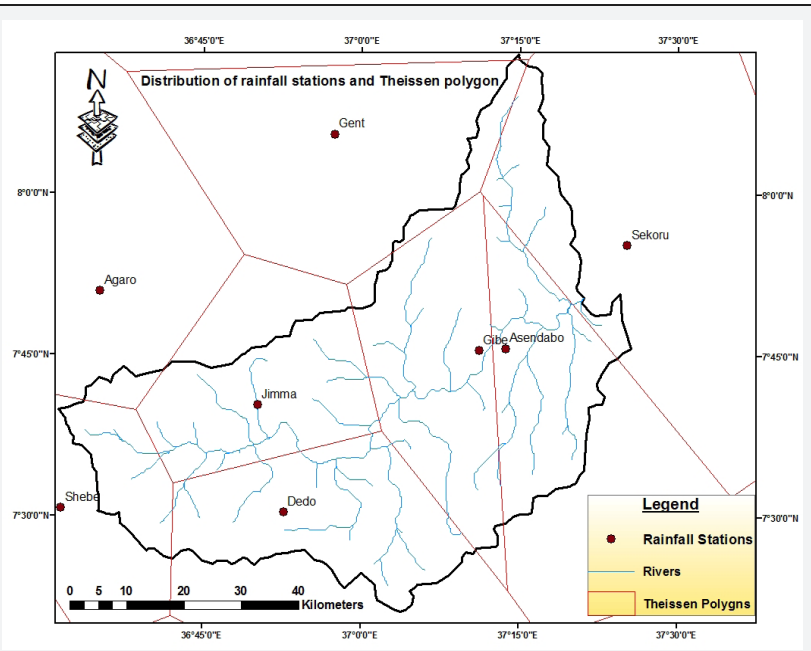

Figure 3: Distribution of rainfall stations and Thiessen polygon.
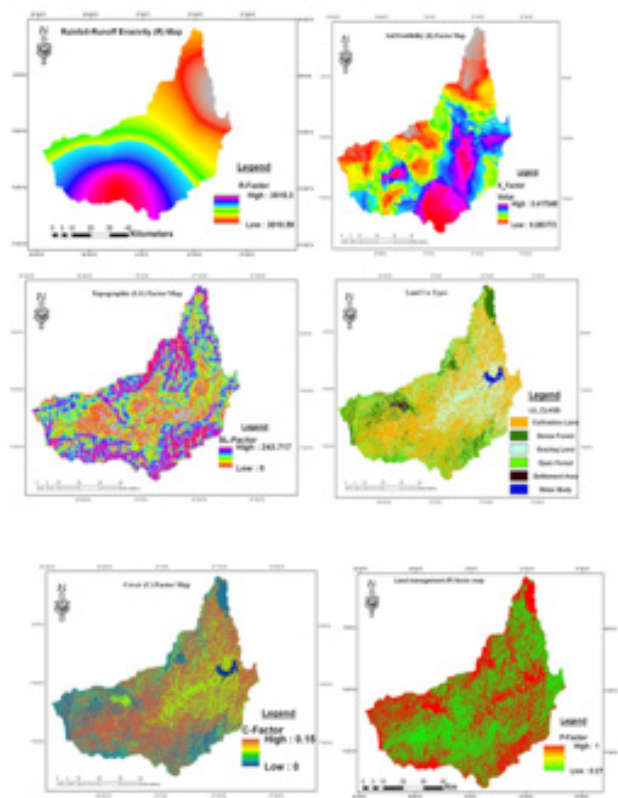

Figure 4: Spatial distribution of rainfall runoff erosivity $(R)$ factor. 
Topographical factor constitutes two factors which are slope length (L) and slope steepness (S). Slope length (L) is the effect of slope length on erosion. Slope steepness (S) represents the effect of slope steepness on soil erosion. The mean LS factor value using USPED method was resulted 1.163 ranging from 0 to 243.717 with the standard deviation of 5.00. The highest value was observed at the boundaries of the catchment which had high elevation and lowest near the river at the middle or bottom of the catchment Cultivation land was the dominating land use type followed by grazing land, while settlement area was the smallest land use type in the catchment. For each land use types, the corresponding $\mathrm{C}$-values were assigned using the values suggested by different researchers and for this study the assigned C-values for different land use types are included in Appendix 1. C-factor map of the catchment was generated by reclassifying land use types, in spatial tool analysis, with this $\mathrm{C}$-value. Accordingly, the weighted C-value of the catchment was resulted 0.11 with a standard deviation of 0.12 . The only support practice observed in the study area was contour farming, ploughing along the contour, and some new bunds on some areas of cultivation land only. In addition, there was no in situ conservation practices on cultivation or cropped lands. According to the P-factor values adapted for Ethiopia by Nyssen et al. [25] for different land uses types P-value of 0.27 was used for cultivation land and 1 for other land use types. On the bases of the area of land use types the weighted P-value of the catchment was resulted 0.43 with the standard deviation of 0.28 . The assigned P-values for Ethiopia by Nyssen et al. [25] were given in Appendix 2.

\section{Estimated Annual Soil Loss}

RUSLE parameters were organized in a grid format with a cell size of $30 \mathrm{~m} \times 30 \mathrm{~m}$ and the soil loss map of the catchment was produced by overlaying RUSLE parameters. The computed mean annual soil loss of the catchment was found to be 62.98ton ha $^{-1}$ year ${ }^{-1}$ with a range of 0 to 983.14 ton $\mathrm{ha}^{-1}$ year $^{-1}$ and standard deviation of 168.69 . The total soil loss of the catchment was resulted $26.56 \times 106$ tones year $^{-1}$ (Figure 5). The finding of this study is in agreement with the findings of previous studies done in the nearby areas and other parts of the country. For example, findings by FAO [28], Hurni et al. [5], Tesfu and Zenebe, [29-31]. The findings of the researchers were given as below. According to FAO [28], the mean annual soil loss of the highlands of Ethiopia ranges from 16 to 300 ton ha $^{-1}$ year $^{-1}$ from pasture, ranges and cultivated fields throughout Ethiopia. Hurni et al. [5] reported soil erosion from cultivation land in Ethiopian highlands reaches 130 - 170 ton ha $^{-1}$ year $^{-1}$. Bewket and Teferi [30] have found mean annual soil loss ranging from 7-243 t/ha/yr for a catchment in the Blue Nile basin while Hawando [31] found the annual soil loss of Ethiopia highlands ranges from 16-300 ton ha-1year-1 from pasture ranges and cultivated fields.

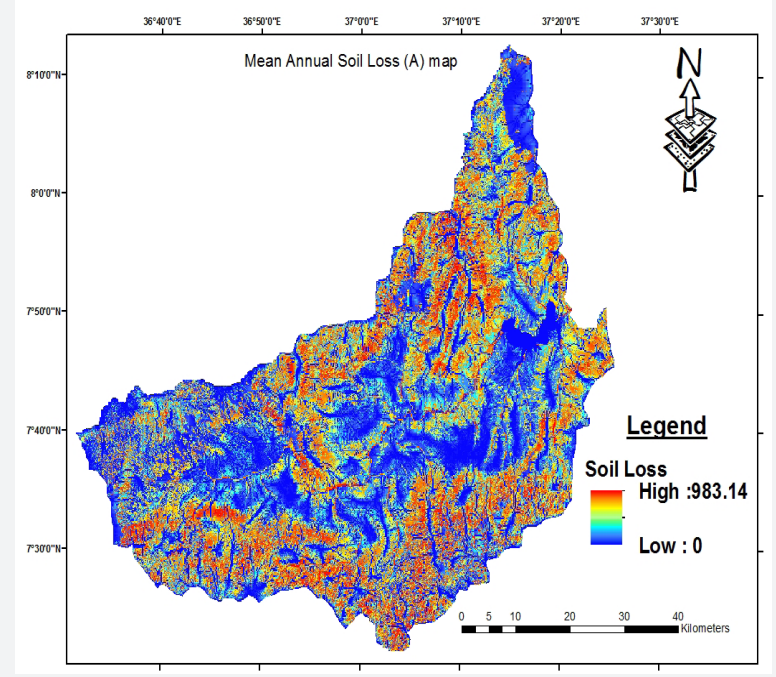

Figure 5: Spatial distribution of mean annual soil loss map.

Shiferaw [31] found an erosion rate in the range of 80- 54 ton ha $^{-1}$ year $^{-1}$ in northern Ethiopia. Adeba [10] conducted a research in two woredas (Dedo and Tiro Afeta) in the catchment using RUSLE and reported that the mean soil loss rate in the woredas ranges from 1.59 to 31.7 ton ha $^{-1}$ year $^{-1}$ which was similar to the result of this study. A preliminary study conducted on soil loss and runoff at Jimma Agricultural Research Center (JARC) using experimental runoff plot by Tesfu and Zenebe, (2006) came out with the result of 82.3 ton ha $^{-1}$ year ${ }^{-1}$. They also reported that the mean soil loss from bare land, coffee, Taro, Maize, and Teff was $82.3,11.4,4.3,9.8$ and 19.4 respectively. JARC was located at the upper part of the Gilgel Gibe-1 catchment and the result reported by them was comparable or almost similar to the finding of this study. The mean annual potential soil loss of Jima zone for the year 2001 and 2013 was reported 48.1 ton ha $^{-1}$ year ${ }^{-1}$ and 60.9 respectively by Beshir and Awdenegest, (2015) which was done by the help of GIS-based USLE approach.

\section{Prioritization of Sub-watersheds}

As shown in Table below $35.2 \%$ of the catchment was found under slight soil loss class and $20.44 \%$ of the catchment was under very severe soil loss class which is $>80$ t ha $^{-1}$ year $^{-1}$. Generally, about 


\section{International Journal of Environmental Sciences \& Natural Resources}

$56.1 \%$ of the catchment area have soil loss greater than tolerable level, which is $11 \mathrm{t} \mathrm{ha}^{-1}$ year-1 $^{-1}$ as suggested by [26] (Table 1). Sub watersheds with high mean annual soil loss and mean sediment yield were given priority and with the least value of mean annual soil loss and mean sediment yield were given last priority for soil and water conservation implementation. Accordingly, based on mean annual soil loss SW4, SW3, SW5, SW6, SW9, SW8, SW7, SW2 and SW1 got 1 to 9 priorities respectively. Mean annual soil loss of sub watershed with first priority was 86.85 ton ha-1 year${ }^{1}$ and 49.13 -ton ha $^{-1}$ year $^{-1}$ for the last priority. There was no big difference between priorities of sub watersheds based on mean annual soil loss and mean sediment yield (Table 2).

Table 1: Severity class and area coverage based soil loss class (tons ha $^{-1} y_{e a r^{-1}}$ ).

\begin{tabular}{|c|c|c|c|}
\hline Soil loss class & Severity class & Area coverage $\left(\mathrm{km}^{2}\right)$ & $\%$ of area coverage \\
\hline 0 to 5 & Slight & 1484.66 & $35.20 \%$ \\
\hline 5 to 10 & Medium & 366.82 & $8.70 \%$ \\
\hline 10 to 20 & High & 463.53 & $10.99 \%$ \\
\hline 20 to 40 & Very high & 511.15 & $12.12 \%$ \\
\hline 40 to 80 & Severe & 529.67 & $12.56 \%$ \\
\hline$>80$ & Very severe & 862.17 & $20.44 \%$ \\
\hline
\end{tabular}

Table 2: Priority of sub-watersheds based on mean annual soil loss.

\begin{tabular}{|c|c|c|c|c|}
\hline \multirow{2}{*}{ Sub -Watersheds } & \multicolumn{2}{|c|}{ Area } & \multirow{2}{*}{$\begin{array}{c}\text { RUSLE Model out put } \\
\text { Mean Annual Soil Loss (ton } \text { ha }^{-1} \mathbf{y r}^{-1} \text { ) }\end{array}$} & \multirow{2}{*}{ Priority by mean annual soil loss } \\
\hline & $\left(\mathrm{Km}^{2}\right)$ & (\%) & & \\
\hline SW1 & 579 & 13.73 & 49.13 & 9 \\
\hline SW2 & 555 & 13.16 & 50.14 & 8 \\
\hline SW3 & 328 & 7.78 & 75.02 & 2 \\
\hline SW4 & 308 & 7.3 & 86.755 & 1 \\
\hline SW5 & 693 & 16.43 & 68.5 & 3 \\
\hline SW6 & 578 & 13.7 & 66.53 & 4 \\
\hline SW7 & 382 & 9.06 & 55.25 & 7 \\
\hline SW8 & 541 & 12.83 & 63.65 & 6 \\
\hline SW9 & 254 & 6.02 & 65.41 & 5 \\
\hline \multicolumn{3}{|c|}{ Weighted Mean } & 62.98 & \\
\hline
\end{tabular}

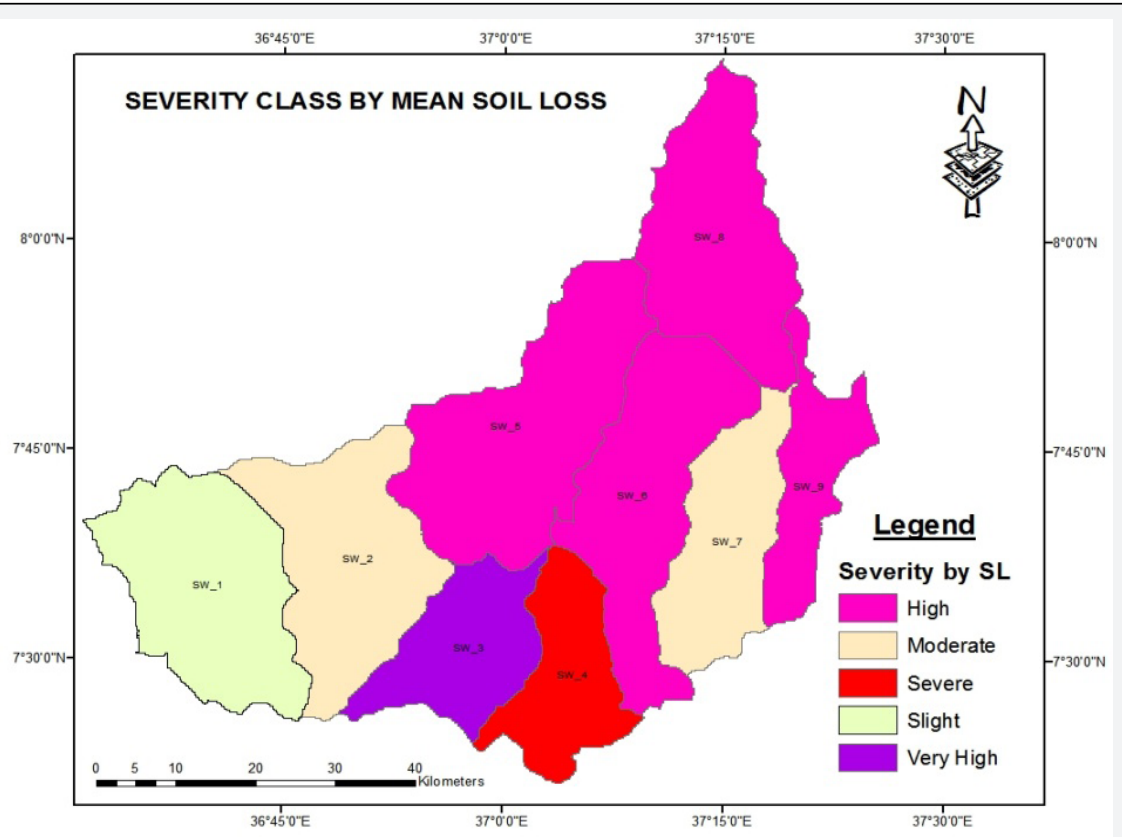

Figure 6: Severity class of sub watersheds of the catchment by mean annual soil loss. 
Finally, the catchment was classified based on mean annual soil loss of each sub watersheds as $40-50$-ton ha $^{-1}$ year-1 $^{-1}$ slight, 50 - 60ton ha ${ }^{-1}$ year $^{-1}$ moderate, 60 - 70 ton ha $^{-1}$ year $^{-1}$ high, $70-$ 80 ton ha $^{-1}$ year ${ }^{-1}$ very high and $>80$-ton ha-1yr-1 severe. Similarly, on the bases of mean sediment yield of sub watersheds the catchment was classified as 5 - 7-ton ha ${ }^{-1}$ year-1 $^{-1}$ slight, 7 - 9ton ha ${ }^{-1}$ year ${ }^{-1}$ moderate, 9 - 11ton ha ${ }^{-1}$ year $^{-1}$ high, 11 - 12 ton ha ${ }^{-1}$ year ${ }^{-1}$ very high and $>12$ ton ha ${ }^{-1}$ year ${ }^{-1}$ severe. On the bases of mean soil loss SW5, SW6, SW8 and SW9 were under high soil loss severity class while SW3 and SW4 were under very high and severe soil loss severity class respectively. Only SW2 and SW7 were under moderate class while only SW1 was under slight severity class (Figure 6).

\section{Conclusion and Recommendations}

Soil erosion is a serious problem in the Ethiopian highland areas that increased sedimentation of reservoirs and lakes. To control soil erosion at a catchment identification of erosion hot spot areas is need, but previous studies didn't identified this erosion hotspot areas in the study area. Because of this, the study was conducted with the objective of soil loss estimation and prioritization of subwatersheds for soil and water conservation planning by GIS based RUSLE models in the catchment. The RUSLE model parameters, which were rainfall-runoff erosivity, soil erodibility, topographic factor, cover factor and land management factor, were resulted with a weighted mean value of 3198.97 MJmmha-1h-1year-1, 0.358 ton ha h ha-1 ${ }^{-1} \mathrm{~J}-1 \mathrm{~mm}^{-1}, 1.163,0.11$ and 0.43 respectively. Accordingly, mean soil loss of Gilgel Ghibe-1 catchment was found 62.98 ton ha $^{-1}$ year $^{-1}$ which was about $26.56 \times 106$ ton year-1. Areas with high mean annual precipitation, highly susceptible soils (high organic matter content and loose soil structure), steep slopes, less surface coverage and no management practices resulted high soil loss. On the bases of mean annual soil loss found by this study, about $43.9 \%$ of the catchment have a soil loss less than tolerable erosion level (11 ton ha $^{-1}$ year $^{-1}$ ). High and very high erosion class covers about $11 \%$ and $12 \%$ of the overall catchment area respectively.

And severe soil loss class covers $12.56 \%$ of the catchment area while, about $20 \%$ of the catchment is under very severe soil loss class. Soil erosion 'hotspot' areas of the catchment was identified on the bases of both mean annual soil loss and sediment yield through sub watershed prioritization. On the bases of mean annual soil loss SW4, SW3, SW5, SW6, SW9, SW8, SW7, SW2 and SW1 got priority 1 to 9 respectively; and SW4, SW5, SW3, SW6, SW7, SW8, SW9, SW2 and SW1 were prioritized similarly 1 to 9 respectively on the bases of mean annual sediment yield of the sub watersheds. According to sub-watershed priorities appropriate soil and water conservation structures with proper design should be implemented to minimize the amount of top soil removed from the area and siltation of Gilgel Ghibe- 1 reservoir for healthy ecosystem. Lands adjacent to the reservoir should be protected as a buffer zone. Proper land use planning should also be applied properly, especially on high slope areas (Appendix 1 \& 2).

\section{References}

1. Adeba G (2016) Estimation of soil loss using Revised Universal Soil Loss Equation and determinants of soil loss in Tiro Afeta and Dedo districts of Jimma zone, Oromia Regional State, Ethiopia. Trends Agric Econ 9(1-3): 1-12.

2. Adugna T, Saathoff F, Seleshi Y, Gebissa A (2013) Evaluating the Effectiveness of Best Management Practices in Gilgel Gibe Basin Watershed-Ethiopia. J Civil Eng Archite 7(10): 1240-1252.

3. Beshir K, Awdenegest M (2015) Identification of soil erosion hotspots in Ima Zone, Ethiopia, using GIS based approach. Ethiopian journal of environmental studies and management 8(suppl 2): 926-938.

4. Bewket W, Teferi E (2009) Assessment of soil erosion hazard and prioritization for treatment at the watershed level: case study in the Chemoga watershed, Blue Nile basin, Ethiopia. Land Degrade Dev 20(6): 609-622.

5. Bezuayehu T (2006) People and dams: environmental and socioeconomic changes induced by a reservoir in Fincha'a watershed, western Ethiopia. Tropical Resource Management Papers 75. Wageningen University, Wageningen, the Netherlands.

6. Broothaerts T, Kissi E, Poesen J, Van Rompaey A, Getahun K, et al. (2012) Spatial patterns, causes and consequences of landslides in the Gilgel Gibe catchment, SW Ethiopia. Catena 97(2012): 127-136.

7. Demissie, Saathoff F, Sileshi Y, Gebissa A (2013) Climate change impacts on the streamflow and simulated sediment flux to Gilgel Gibe 1 hydropower reservoir Ethiopia. European International Journal of Science and Technology 2(2): 63-77.

8. Devi R, Subalewu T, Worku L, Bishaw L, Abebe B (2008) Assessment of siltation and nutrient enrichment of Gilgel Gibe dam, Southwest Ethiopia, Bio. Resource Technology 99(5): 975-979.

9. FAO and UNEP (1984) Provisional Methodology for Assessment and Mapping of Desertification. FAO, Rome, Italy.

10. FAO-UNESCO (1974) FAO/UNESCO Soil Map of the World 1:5.000.000, UNESCO, Paris. Fubelli G, Abebe B, Dramis, F, Vinci S (2008) Geomorphological evolution and present-day processes in the Dessie Graben (Wollo, Ethiopia). Catena 75: 28-37.

11. Fernandez C, Wu JQ, McCool DK, Sto“ckle CO (2003) Estimating water erosion and sediment yield with GIS, RUSLE, and SEDD. J Soil Water Conserv 58(3): 128-136.

12. Ferro V, Porto P (2000) Sediment delivery distributed (SEDD) model. J Hydrol Eng 5:4(411): 411-422.

13. Hawando T (1995) The Survey of the Soil and Water Resources of Ethiopia. UNU/Toko.

14. Hurni H, Abate S, Bantider A, Debele B, Ludi E, et al. (2010) Land Degradation and Sustainable Land Management in the Highlands of Ethiopia.

15. Jain SK, Kumar S, Varghese J (2001) Estimation of soil erosion for a Himalayan watershed using GIS technique. Kluwer Academic Publishers. Water Resources Management 15(1): 41-54.

16. Jim Pelton, Eli Frazier, Erin Pickilingis (2012) Calculating Slope Length Factor (LS) in the Revised Universal Soil Loss Equation (RUSLE).

17. Kebede T, Mikru Z (2006) Effect of Different Cover Crops on Runoff and Soil Loss. Proceeding: Workshop organized by UNESCO chair in water resources entitled "International Sediment Initiatives Conference (ISIC). Khartoum p. 12-15.

18. Kidane D, Alemu B (2015) The Effect of Upstream Land Use Practices on Soil Erosion and Sedimentation in the Upper Blue Nile Basin, Ethiopia. Review. Research Journal of Agriculture and Environmental Management. 4(2): 55-68. 
19. Lane LJ, Kidwell MR, Weltz MA (2000) Watershed sediment yield and rangeland health. International Journal of Sediment Research 15(1): 51-59.

20. Mati BM, Veihe A (2001) Application of the USLE in a savannah environment: Comparative experiences from East and West Africa. Singapore Journal of Tropical Geography 22(2): 138-155.

21. Morgan RPC (2005) Soil erosion and conservation ( $3^{\text {rd }}$ edn.). National soil resource institute, Cranfield University.

22. Nebiyu A (2010) The Sustainable use of Soil Resources of Gilgel Gibe dam catchment. Proceeding of the national workshop in integrated watershed Management on Gibe-Omo basin. Jimma University and Gilgel Gibe site p. 39-42.

23. Negash T, Mesfin K (2011) Proceeding of the national workshop in integrated watershed management on gibe - omo basin, PHE Ethiopia Consortium.

24. Nyssen J, Poesen J, Haile M, Moeyersons J, Deckers J, et al. (2009c) Effects of land use and land cover on sheet and rill erosion rates in the Tigray highlands, Ethiopia. Zeitschrift für Geomorphologie 53(2): 171-197.

25. Nyssen JW, Clymans K, Descheemaeker J, Poesen I, Vandecasteele $\mathrm{M}$, et al. (2010) Impact of soil and water conservation measures on catchment hydrological response a case in north Ethiopia. Hydrol. Processes 24(13): 1880-1895.

26. Pandey V, Chowdary M, Mal BC (2007) Identification of critical erosion prone areas in the small agricultural watershed using USLE, GIS and remote sensing. Water Resources Management 21(4): 729-746.

This work is licensed under Creative Commons Attribution 4.0 License

DOI: 10.19080/IJESNR.2018.15.555923
27. Renard KG, Foster G, Weesies G, McDool D, Yoder D (1997) Predicting Soil Erosion by Water: A Guide to Conservation Planning with the Revised Universal Soil Loss Equation (RUSLE). Agricultural Handbook 703, USDA-ARS

28. Shiferaw A (2011) Estimating Soil Loss Rates for Soil Conservation Planning in the Borena Woreda of South Wollo Highlands, Ethiopia. J. Sustainable Development in Africa 13(3): 87-106.

29. Tadesse S, Milesi JP, Deschamps Y (2003) Geology and mineral potential of Ethiopia: a note on geology and mineral map of Ethiopia. Journal of African Earth Sciences 36(4): 273-313.

30. Tripathi MP, Raghuwanshi NS (2003) Identification and prioritization of critical sub watersheds for soil conservation management using the SWAT model. Biosystems Engineering 85(3): 365-379.

31. Tsegaye D, Tsunekawa M, Tsubo A, Haregeweyn MN (2012) Dynamics and hotspots of soil erosion and management scenarios of the Central Rift Valley of Ethiopia. Int J Sedimen Res 27(1): 84-99.

32. Wischmeier WH, Johnson CB, Cross BV (1971) A soil erodibility nomograph for farmland and construction sites. Journal of Soil and Water Conservation 26: 189-193.

33.Zelalem B (2006) Estimation of Rainfall Erosion Potential and Development of Iso-Erodent Map of Oromia Regional state Based on Daily Rainfall Amount. An Msc Thesis Presented to the school of Graduate Studies of Haramaya University p. 62.

\section{Your next submission with Juniper Publishers} will reach you the below assets

- Quality Editorial service

- Swift Peer Review

- Reprints availability

- E-prints Service

- Manuscript Podcast for convenient understanding

- Global attainment for your research

- Manuscript accessibility in different formats

( Pdf, E-pub, Full Text, Audio)

- Unceasing customer service

Track the below URL for one-step submission https://juniperpublishers.com/online-submission.php 